\title{
Biotechnology and the Cell Cultures of Woody Perennials
}

\author{
by
}

\author{
Don J. Durzan ${ }^{1}$
}

In Canada, biotechnology is generally viewed as the use of a biological process to provide goods and services through microbial, plant or animal cells, or their constituents. My objective is to briefly review the present status of biotechnology at the cellular level as it relates to production cycles based on woody perennials.

\section{New Research Directions}

New research directions are based on innovation, that is, changes that lead to increased production of goods and services in product-use cycles (Fig. 1). Goods are derived from the commodities and bulk materials that comprise the genetic base; services are derived from the management of the genetic base and materials in these cycles.

\section{Domestication and New Genetic Variation}

In forestry the diverse wild, natural populations of forest trees are both a genetic reservoir and the raw materials for producing goods. Trees may be grown for lumber, fibre, pulp, energy, chemical feedstocks, recreation facilities and wildlife management. During the early development of eastern Canada, the best trees were high-graded (Lower 1938). However, for most native Canadian trees the genetic variation is still broad. In other species (such as red pine), genetic variation is limited and new sources must be sought. Elite traits must be identified and introduced into the production cycle using mass-propagation methods that exploit the concept of totipotency.

The main barriers to progress so far have been the long life cycle of explants and difficulties in applying current biotechnologies to mature and proven trees. Suitable donor tissues are difficult to maintain in an aseptic condition and must be rejuvenated for clonal propagation.

Cellulose and wood are not always required from woody perennials that yield fruit and nuts. These commodities are sought from dwarf trees amenable to mechanical cultivation and harvesting. Many elite trees with superior traits are clones, and considerably more new genetic variation is required for tree improvement programs. Furthermore, the ideal tree would exhibit many traits, rather than a single gene difference. Nevertheless, the search has begun for traits based on easy-

1Department of Pomology, University of California, Davis, California. to-manipulate single-gene differences that may be introduced and expressed in the modified germplasm. Examples are blister rust in Pinus sp. (Kinloch et al 1970) and herbicide resistance in forest trees (Calgene 1984).

In diverse populations of woody perennials, an arbitrary but simple approach to domestication is to capture and multiply genetic gains in elite, proven trees. By genetic gains we mean heritability of elite traits. Biotechnologies using cell and tissue culture regeneration systems should contribute to efficiencies and economics in production cycles.

\section{Breeding strategies}

Cell and tissue culture and recombinant DNA methods are applicable in many breeding strategies - mutation, hybridization, selection, somaclonal and gametoclonal variation and direct gene transfer to plants. Ryder (1984) has identified some fallacies in planning and managing research in plant breeding.

For cell and tissue culture, control over reactions in flasks and the development fate of cells are paramount. The recombinant DNA and direct gene transfer methods (Paszkowski et al 1984) are sophisticated; yet much of the biology of the target organism is even more so. Spectacular results seem to be unlikely because of the complexity of problems and the wide range of disciplines needed to establish research teams and pilot studies. The value of trees and their products may have to increase substantially before exploitation of these methods become cost-effective. The challenge is to pick the right opportunities.

\section{Capturing genetic gains}

As with micropropagation (cf. preceding article by Thorpe, Durzan and Campbell 1974; Durzan 1982, 1985c), somatic embryogenesis from explants or cell suspension cutture could become the vehicle to introduce elite traits into forest trees. This assumes that somatic embryogenesis is true-to-type and that traits are expressed in a timely and reliable fashion. Unfortunately we have little information on how to identify quickly elite traits (Tables 1 and 2).

Nevertheless, cell suspension technologies allow investigators to study and apply selection pressures for traits to be captured. If processes and expressions are true-to-type, complex genetic traits (such as hybrid vigour normally lost in 


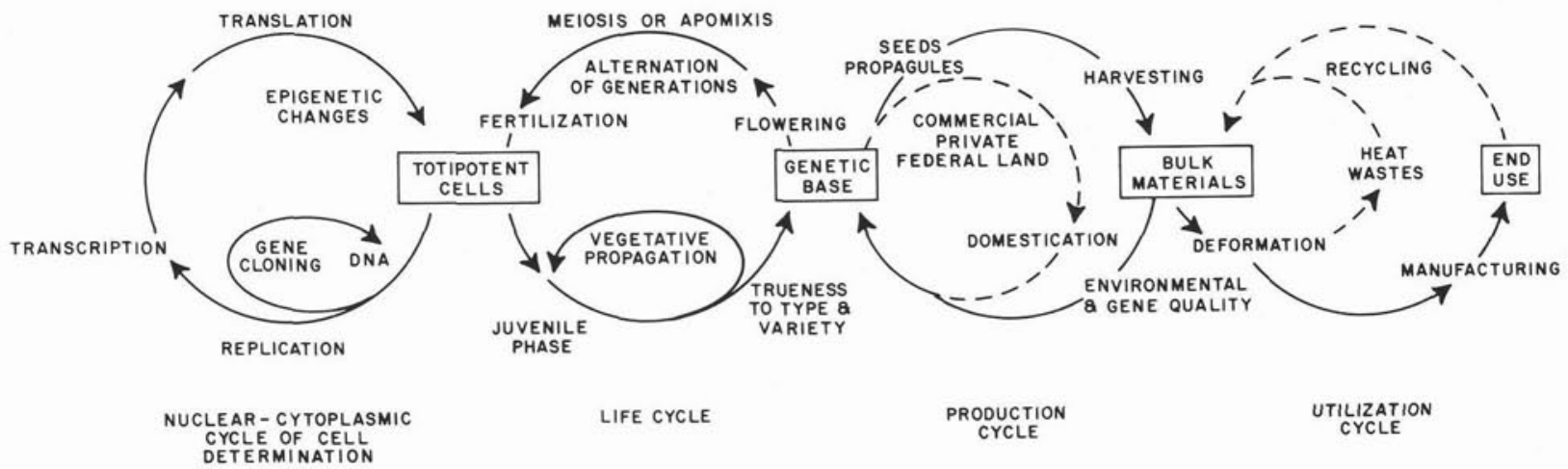

Figure 1. Production-use cycles in Forestry. Tree improvement of woody perennials based on a series of production cycles. Production is depicted arbitrarily at four stages (cell, life cycle, forest production, product use). Production is cyclical and ultimately depends on our existing but renewable germplasm resources. The output for each cycle serves as an input to another in a sequence leading to an end use. Through biotechnology we have an opportunity to shorten and engineer specificity into each cycle. Biotechnologies offer efficiency in producing end products (boxes) for each cycle.

At the cell level, genetic gains for tree improvement are captured by cell and tissue culture. The expression of totipotency and true-to-type processes involve natural polymer-producing systems (DNA, RNA, protein, cellulose). Recombinant-DNA methods permit the cloning of elite genes and their introduction into the genetic base through totipotent cells. Gene expression is mediated by interactions between the nucleus and cytoplasm, and in some instances can lead to genetic transformations or phase change in woody perennials (Brink 1962). For the tissue culturist, the output of this cycle is a totipotent cell.

The life cycle is launched after fertilization or by cell and tissue culture using totipotent cells. If profitable, veget- ative propagation becomes a useful subcycle associated with the life cycle. Its advantage is that the additive and nonadditive genetic expression can be captured. Nonadditive traits such as hybrid vigour and disease resistance are often lost by traditional breeding methods

Genetic gains may be captured from proven mature specimens for domestication. In the production cycle, trees and their bulk materials are produced for the market place. Rapid wood production in juvenile trees is needed in forestry but is sometimes avoided where trees are grown for seed, fruit and nut production. The perennial habit and improved cultural systems suited to specific microclimates can be exploited to minimize alternate bearing and unpredictability of the crop.

For the utilization cycle, bulk materials derived from a diversity of germplasm allow for substitutions of materials agricultural chemicals, plant-machine compatibility, energy savings and chemical field studies. We can search for ways to extend the shelf life of seeds and commodities through low temperatures, gaseous atmospheres, packaging and transportation. Quality attributes should be identified and introduced back into the breeding strategies to improve the genetic base.

Table 1. Anticipated genetic gains resulting from the first generation of breeding and its effect when improved trees are managed under intensive silviculture systems.

\begin{tabular}{|c|c|c|c|}
\hline $\begin{array}{l}\text { Tree } \\
\text { species }\end{array}$ & $\begin{array}{l}\text { Characters } \\
\text { under improvement }\end{array}$ & $\begin{array}{l}\text { Anticipated genetic } \\
\text { gain }(\%)\end{array}$ & $\begin{array}{l}\text { Increase as result of genetic gain } \\
\text { postulated }\end{array}$ \\
\hline Red pine & Height growth & 3 & $750000 \mathrm{~m}^{3} /$ rotation \\
\hline White pine & Resistance to blister-rust & 13 & $\begin{array}{l}\text { Double per hectare yields; } 4 \mathrm{X} \text { hectares planted; } \\
\text { losses to rust in young plantings greatly } \\
\text { decreased }\end{array}$ \\
\hline Jack pine & Form, height & 11 & Up to $253750 \mathrm{~m}^{3} / \mathrm{yr}$ \\
\hline Shortleaf pine & Height & 9 & $1000 \mathrm{~m}^{3} / \mathrm{ha}$ \\
\hline White spruce & Volume & 23 & $\begin{array}{l}\text { Nearly } 5000 \mathrm{~m}^{3} / \mathrm{yr} \text { harvested and over } 18000 \\
\mathrm{~m}^{3} / \mathrm{yr} \text { additional }\end{array}$ \\
\hline Black spruce & Volume & 18 & 32.6 million $\mathrm{m}^{3} /$ rotation \\
\hline Yellow birch & Apical dominance & 10 & $210000 \mathrm{~m}^{3} /$ rotation \\
\hline $\begin{array}{l}\text { Black cherry } \\
\text { cherry }\end{array}$ & $\begin{array}{l}\text { Diameter growth } \\
\text { Apical dominance }\end{array}$ & $\begin{array}{l}10 \\
25\end{array}$ & Shorter rotations: $7.95 \mathrm{~m}^{3} /$ ha rotation \\
\hline
\end{tabular}

Source: USDA Forest Service (1971)

breeding programs) can be captured. This approach requires close cooperation with the breeders. It is a tool that may supplement but not replace existing tree improvement programs and breeding strategies.

Reliable correlations for gene expression between test populations of juvenile and mature trees are required to shorten the testing time. This is easily said; in practice it is not easily done (Timmis 1984). Cell and tissue cultures from the test and control populations provide a convenient laboratory assay method, provided that simple tests for gene expression are available. One problem here is the same as that for correlations between traits in juvenile and mature trees. This approach has another drawback - our lack of baseline knowledge of the physiology and biochemistry of trees at all stages of the cell life and production cycles. Because trees are perennial the necessary studies may take decades to 


\section{Table 2. Strategies for improving forest trees and exploiting cells.}

Collect, maintain, evaluate, document and distribute genetic resources

Understand the genome organization, gene structure, genetic variability and geographic distribution of species. This includes their taxonomic, molecular and cytological relationships with closely related species

Identify, evaluate and select for elite traits. Cost-effective, largescale, rapid-screening and reliable methods are needed

Understand the process controls of gene expression and the genetic mechanisms controlling the inheritance and transfer of important traits (simple and complex)

Create new genetic variation and useful, reliable biotechnologies for breeders. This involves the development of methods for the transfer of desirable genes between and within species

Breed, propagate, release and maintain elite trees

Produce high quality seed and nursery stock (genetic base) for distribution to production systems

Reliable, low-risk scale-up of high-quality germplasm and products derived from trees

Encourage education and innovation with genetic systems and exploitation of cellular systems and biomimetic processes

Assess impact of new and existing biotechnologies for user and consumer

complete. By contrast, control over the activities of cells may be explored by techniques already established in biochemical engineering. In this approach processes in cells may not have to correlate with those in the whole plant.

With long-lived woody perennials, time is a major factor that can be shortened by exploiting cells. Changes and cutbacks in government programs, discourage long-term studies, testing and the development of biotechnology in forestry schools.

\section{Basic research}

Basic research with trees is often done best in universities. However, the continuity of effort needed for woody perennials may not be easy in a university setting. Canadian government support of tree biology research has been controversial and unpredictable. The university should provide a training ground for a wide range of genetic strategies and biotechnologies. This should be done in cooperation with industry and federal and provincial governments. Guidelines for industry-sponsored research at universities in the USA may be applicable to $\mathrm{Ca}$ nada (Varrin and Kukich 1985).

\section{Production cycles}

We can add value to our products and services using high technology (Shapiro 1980). Value added can take the form of: shortening the cycle; of energy, materials and space by cultivating the early stages of the development in vitro; of reducing risks by protecting vulnerable juveniles from insects, diseases and environmental hazards; of improving marketability of the product because of its superior traits; or ease in cultivation. Superior traits could include suitability of trees for machine harvesting and uniformity of shape and fibre quality. Not all opportunities are related entirely to cullular biotechnologies.

The sequence of steps in production and service cycles determines the products that in turn feed a use cycle. We are dealing with renewable resources, but costs may include non- renewable resources such as fossil fuels, particularly in heavily mechanized silvicultural and manufacturing operations. It is possible that production cycles can become self-sufficient in energy and materials.

With biotechnology there are many variations in production-use cycles. Not all are related to multiple-use trees or to whole-tree use. Biotechnologies may be developed with cells that offer new possibilities for the use of tree cell products.

\section{Quality and process control}

Before biotechnologies can emerge they must be costeffective and reliable, and their processes must be understood and controlled. Cells of woody perennials are far more complex genetically than microorganisms. Currently there are no genetically engineered plant products on the market, although commercial opportunities for the agricultural, food processing, and chemical markets are large.

Speculations about the potential of genetic engineering with tree cells assume that the transfer and scale-up of knowedge and technology based on simple model systems is a matter of fact. This simply is not true. Had it been so, the biotechnology of trees based on cell and tissue culture and recombinant DNA would have developed much earlier in spite of the low value of forest products. The new biology will require refined technologies before application. Otherwise, through overpromising, truly innovative opportunities in research and development may be lost for generations.

Hence tree biotechnology will have to evolve new principles based on mathematics, physics and chemistry before applications can be systematized by computer-aided design and manufacture. Once this is done there is no doubt that substantial savings in time and resources can be achieved.

\section{Cell Culture}

The role of cell and tissue culture in the forest industry has been described in detail elsewhere (Durzan 1982). The potential uses of tree cells are many. Cells can be grown in large numbers like microorganisms. Much of the technology and knowledge derived from agricultural microbiology (Brill 1981) may someday be applied reliably to cells of woody perennials.

Furthermore, once cells are capable of somatic embryogenesis they are suitable for further genetic manipulation. Selection of superior traits in large populations is more feasible. Selection is a numbers game and cells, because of their generation time, provide the numbers required to find mutants or rare variants. However, to capture these gains we first must regenerate plants from cells.

Regeneration has had limited success with only a few species (Bonga and Durzan 1982). The Canadian Forestry Service in 1969 advertised in trade journals that someday we may grow a forest from cells in a flask (Fig. 2). Lydia Dotto of the Globe and Mail (Nov. 28, 1974, p. 45) described the first tree from cells - the American elm. The approach is feasible but so far the methods are unpredictable and not yet applicable on a large scale (cf. Durzan 1980).

With cell suspensions, the ideal approach to propagation would be synchronized, repetitive somatic embryogenesis (Fig. 3). Once established, somatic embryogenesis could be 


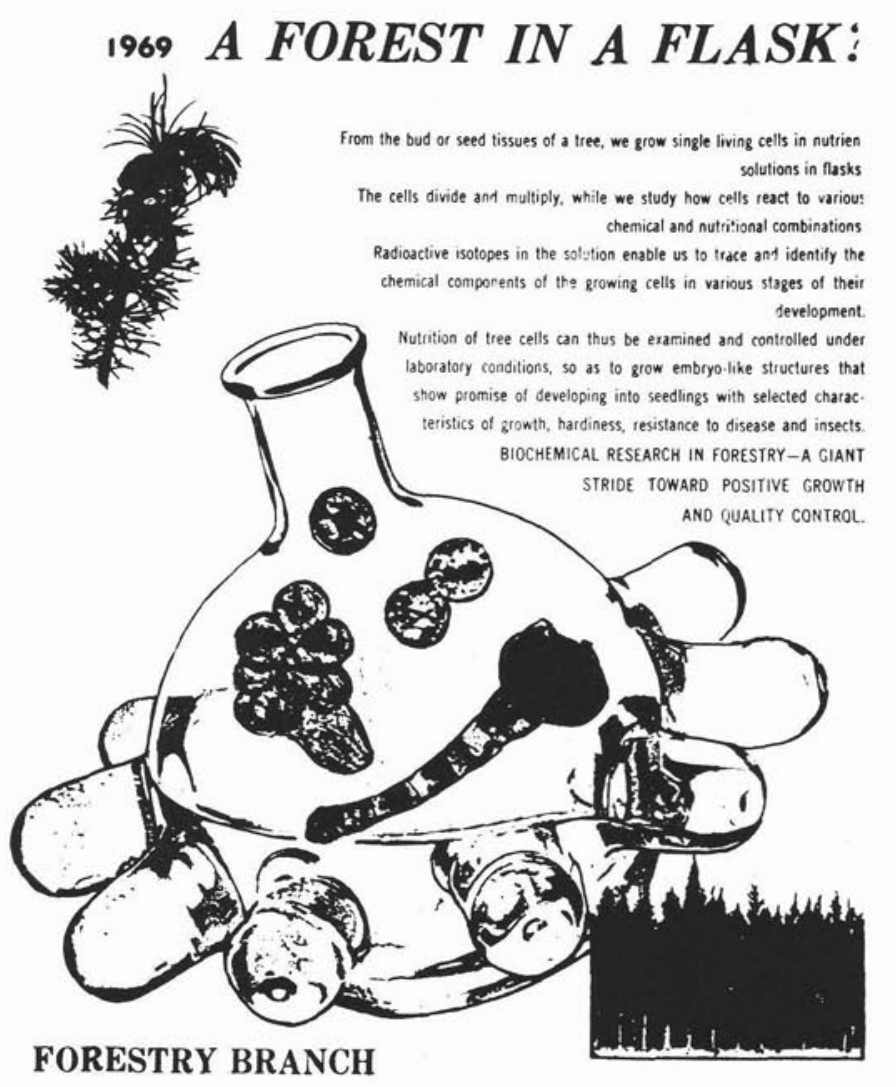

Figure 2. Advertisement placed in 10 trade journals by the Canadian Forestry Service describing a potential biotechnology based on a cellular cloning cycle.

induced on a large scale and mechanized. Again, researchers are far from establishing any form of reliability and process control.

\section{Potential applications}

\section{Basic Strategy}

Potential applications are suggested by savings in time, energy and money in timber production cycles.

With cellular biotechnologies we may someday bypass the problem of unpredictable seed years and nonavailability of seeds by developing artificial seed in cellular cloning cycles (Fig. 3), although this has yet to be accomplished.

Strategies should be directed to obtaining more products and services in our cycles (Fig. 1, Table 3) from a diminishing genetic base and for a rapidly increasing population. From the diminishing genetic base we must domesticate trees and clone quality trees. Above all we must reduce the risks of loss of elite germplasm. Production and services must be local, predictable and efficient.

Biotechnologies fostering new directions contribute to the economic well-being of the country. Before this can

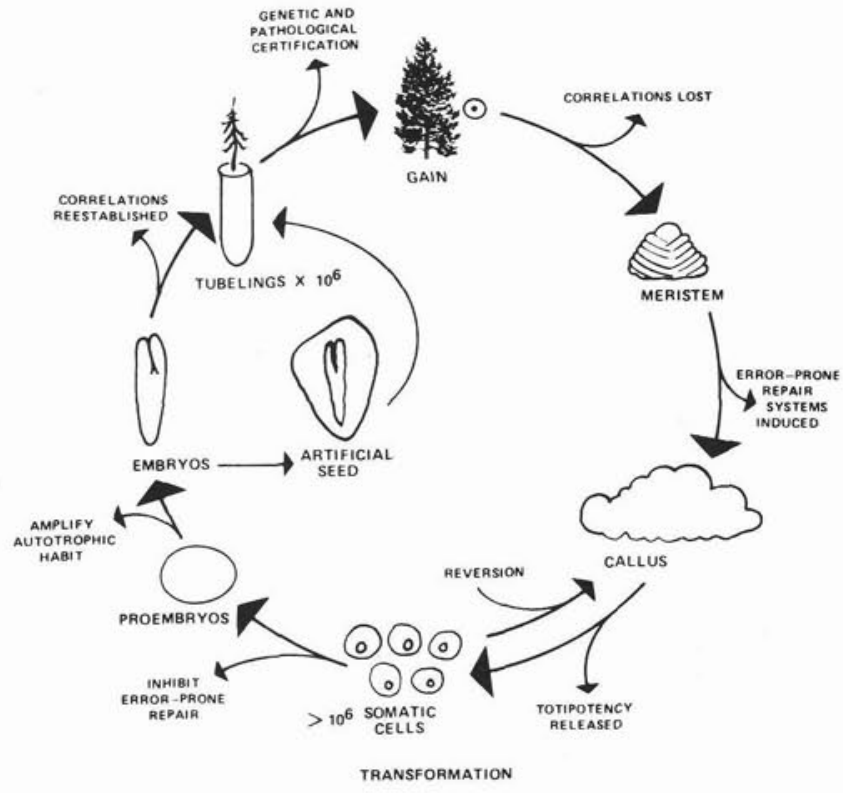

Figure 3. Cellular cloning cycles for artificial seed. Example of cellular cloning cycle for conifers that is applicable to other woody perennials. At the top, meristems (nodal segments, apical and axillary buds) from mature trees or explants from seeds embodying specific genetic gains are used as tissue donors in propagation systems. For mass-propagation by somatic embryogenesis, callus is grown under aseptic conditions. The formation of callus removes many of the physiological and structural correlations found in the donor and may activate error-prone repair systems that are important for true-to-type expressions of totipotency. Under the influence of nutrition, auxins and cytokinins, cells and tissues may regenerate primary meristems. By contrast, in micropropagation, shoot meristems are induced directly on cotyledons and hypocotyls from seeds, or on axillary buds of invigorated shoots. The root is usually induced afterwards. Micropropagation yields up to 50000 copies of the donor tree (Gupta et al. 1983).

In the cellular approach callus is reduced to cells, which are dedifferentiated and rapidly multiplied in diffuse light. Cells are routinely graded for size between 60 to 300 $\mu \mathrm{m}$. When cells are washed and placed in the same medium either lacking auxins and cytokinins or containing other treatments, the cells may be transformed into proembryo-like structures. Occasionally, this step is improved by adding substances that inhibit growth especially where an overproduction of growth regulators occurs.

Someday protoplasts may also be used in place of cells. Somatic embryos develop primary meristems under the somewhat heterotrophic conditions by reestablishing embryonic correlations. Alternatively, sphaeroblasts having a secondary meristem, may develop under the influence of auxins and cytokinins. Here shoots or roots emerge by organogenesis. The aim of the cycle is to masspropagate individuals with elite traits for a mechanized container planting system. One option would be to coat somatic embryos with materials to produce an artificial seed but this technology remains undeveloped. All clones should be tested for trueness to type to establish some form of certification. 
Table 3. Some constraints productivity of trees and nature of research needed to obtain a major effect.

\begin{tabular}{|c|c|c|}
\hline Constraint area & Nature of research & Major effects \\
\hline $\begin{array}{l}\text { Conservation of } \\
\text { genetic resources }\end{array}$ & $\begin{array}{l}\text { Collection and establish- } \\
\text { ment of protected wild popu- } \\
\text { lations and endangered } \\
\text { species; cryobiology, clonal } \\
\text { propagation methods based } \\
\text { on cells }\end{array}$ & $\begin{array}{l}\text { Immediate def- } \\
\text { nition of prob- } \\
\text { lems and pres- } \\
\text { ervation of } \\
\text { endangered } \\
\text { species }\end{array}$ \\
\hline
\end{tabular}

Mass propagation Exploitation of apomixis and to domesticate trees

\section{mass clonal propagation} using micropropagation, somtic embryogenesis and technologies associated with cellular cloning cycles; mechanization of processes

Selection methods Develop simple, rapid selecto capture genetic gains

\section{tion methods for elite traits} and pioneer species, e.g., rapid growth rate, resistance to insects and disease, fibre quality, tree shape and form compatibility with silvicultural methods, biosynthetic competence, herbicide resistance, etc

Juvenility-maturity Methods to invigorate and correlations

\section{rejuvenate mature trees;} rapid methods to assess gene expression, elite traits and interactions with environment

Life cycles

Protoplast fusion, organelle transfer, direct gene transfer and recombinant DNA technologies

Breeding time shortened, leading to important research results within next decade

Modest advan- ces in next decade but applications will relate to spe- cies, length of rotation and commodity sought tion of high-value clones, uniformity and suitability of trees for mechanical har- vesting, methods to control expression of complex sets of genes in a wide range of environments; use of lasers development of biochronot ogy

\begin{tabular}{ll}
\hline Constraint area & Nature of research \\
\hline Genetic variation & Supplement classical \\
and breeding & methods (see text) with \\
strategies & recombinant DNA, proto- \\
& plast fusion, organelle \\
& transfer, vector develop- \\
& ment, somato-gametoclonal \\
& variation and direct gene \\
& transfer
\end{tabular}

Process and quality Molecular basis of gene control to reduce expression, trueness to type, aberrations and ensure trueness to type in gene expression metabolic errors, cytological aberrations, misdirected expressions of totipotency, specific silvicultural methods to deal with highvalue products, understanding of gene and environmental interactions at all stages of life cycle; field evaluation and testing

Environmental factors

\section{Genetic engineering of} mycorrhizae and microorganisms in the rhizosphere and in tree crowns; nitrogenfixation, improved rootstocks, molecular basis for tolerance to acid rain, environmental toxins, salinity, drought, frost, etc. Development of biochronology and integration with satellite data

\section{Major effects}

Major effect within next decade but only at research level; limitations based on need for process and quality control

Modest gains for several decades given current rate of funding and expertise. Annual production may increase two- to threefold

Important results within next two

decades but applications several decades away with major global effects. Substantial risk with genetically engineered

nursery stock and trees in adverse environments
Development of cell products

\begin{abstract}
Development of specific enzymatic methods and proteins, immobilization and encapsulation of cells; application of lectins and understanding and development of mutants and gene expression within cells and tissues; compatibility and genetic stability of cellular fusion products; exploitation and process control of potymeric and fibre systems; DNA/RNA/protein/cellulose/lignin; postharvest storage of somatic embryos and seed (natural and artificial)
\end{abstract}

Two to three decades before pilot processes emerge to test cost-effectiveness and to develop highvalue products happen, however, baseline information must be developed, forestry schools must catch up to developments in biotechnology and we must have an accessible pool of highly qualified scientists. Inadequacies in this respect constitute major limitations in a country that must compete with research and development emerging rapidly on a global scale.

Technology has many faces, some good and others bad. We must guard against those that threaten our environment and genetic diversity. Biotechnologies have their potentially dangerous side (Brill 1985, Baum 1984, Hanson 1984). For this reason Canada should assess the impact of biotechnologies that affect the genetic base, but this review process should not hinder innovative research and development.

\section{Characteristics of cellular biotechnologies}

Biotechnologies aim to add value to products and services in the marketplace. They also, predictably, become obsolete. Although we have a few successes to discuss, more basic research and development problems remain, which are best explored in the context of specific cases. There are, however, some general problems.

Potential applications (see Table 3) depend on demands in the marketplace, with profit as the common yardstick. Unfortunately, there is a difference between test-tubes and fermentors, between pouring things and pumping them and between surface-volume effects and mixing ingredients. Ignoring these 
differences in adopting cellular biotechnologies will cost industry much hard cash.

Furthermore, although forest biology is still international and public, technology is seldom either. The better the scientific work the less likely it is to be published. Government, industry and agencies engaged in biotechnology should employ good scientists to recognize which new scientific dis coveries are suitable for commercial exploitation.

Forest biotechnology will have to become much more quantitative through biochemistry and biophysics than it is today. This is because cells may be used as catalysts to convert raw materials and waste to useful forms such as energy, food and animal feed. Cells can be used to study mineral and chemical cycling, acid rain, mycorrhizal associations, the invasion of diseases, etc. Cells of woody perennials can be encapsulated and immobilized to collect products external to the cellulose wall (Durzan 1985b).

At present, the use of cells of woody perennials to produce antibiotics, vaccines and secondary metabolites is limited. A few historical leads may be worth investigating - the early explorers (Cartier and the Jesuits) used potions from trees, and their remedial effects are more than can be attributable to vitamin C. Experience with cells in suspension suggests that some organization into tissues may be needed to produce secondary metabolic products of value. However, the genetic manipulation of cells and tissues could conceivably contribute to a biosynthetic production in vitro. Biochemistry, microbiology, and chemical engineering might together achieve new applications based on cellular biotechnologies.

Biochemical engineering with plant cells offers a few advantages over traditional chemical engineering. Lower temperatures and pressures can be used. However, genetic instabilities, lack of methods to immobilize cells of woody perennials for continuous production and the need for water in large quantities are disadvantageous. Cells tend to accumur late products internally, and toxic byproducts may develop. Purging cell disruption systems and leaky mutants may be needed.

Chemical feedstocks and lower molecular transformations based on tree cells do not yet have a major role in pharmaceutical and industrial process (O'Sullivan 1984, Vane and Cuatrecasas 1984). The question will always arise: can a chemist do a better job?

As the structure of lignin yields to advances in analytical methods, new markets will appear for tree products in adhesives, foams, films, coating and plastics. The study of cellular systems may help to develop technologies based on the designs of nature.

American scientists have developed herbicide resistance and increased efficiency for nitrogen fixation in some agronomic crops. Target site modification for herbicide resistance in plants is one strategy that may soon be successful. However, everyone acknowledges that much basic research remains to be done before these sorts of biotechnology becomes anything like practical.

Canadian scientists say that damage to forests by acid deposition is a key problem threatening trees in the eastern provinces and that the curb on sulfur dioxide is too narrow an approach. Unfortunately we need a clearer understanding of the action of acid rain at the molecular level. This need is accentuated for some conifers because their cells are among the most sensitive to acid deposition, radiation etc. (Sparrow et al 1970). New ways to measure exposure to toxic substances (carcinogens, mutagens etc.) may help provide a more precise assessment of risks (Maugh 1984). The description of the syndromes, proof of causes and development of tolerant germplasm may eventually involve a wide range of new cellular environmental biotechnologies.

\section{Innovation With Cells}

The ability to synthesize and introduce fragments of DNA and, in some cases, proteins into cells enhances our ability to understand and control gene expression. We simply do not know the extent of gene expressions that can be captured for medicines, vaccines, gene products and chemical feedstocks by the new biotechnologies. Nor have we explored how gene expression can be modified by factors such as light, temperature and drought. Hence the way is open to develop gene expression to exploit low molecular weight transformations and deliver biosynthetic potentials (Venkatasubramanian et al 1983).

The understanding of process controls and information flow in such systems will inevitably lead to new ways of manufacturing. New products and material substitutions are inevitable. As Durzan (1980) pointed out, we may even through the development of biotechnology be able to recover valuable lost traits once expressed in the early evolution of species. Our understanding of how the electromagnetic spectrum affects cellular biotechnology has only begun. With woody perennials, the greatest opportunity is in basic tree biology and molecular genetics, from which new silvicultural principles may be developed.

\section{Some Constraints in Research and Development}

In the applicability of biotechnologies to cellular systems and the domestication process, there are problems to be overcome. Some of them may not be difficult to solve; I list them merely to suggest the progress we may anticipate.

- First, for mass clonal propagation, there are still many unproven cultural systems and recalcitrant species, especially among our more valuable mature and proven woody perennials. We shall have to ask why the current technology does not apply and whether any undiscovered principles can foster success. Tree cells and their hereditary mechanisms are far more complex than many plant and most microbial cells. Cells reach their fullest expression in the body of the tree, for which there is no counterpart with microorganisms. We have a long way to go in controlling the chemical reactions in the solid, liquid and gaseous phases of our culture systems (Fig. 4). We are a long way from prescribing the rules that limit the capacity of plants to fabricate biomass - more specifically DNA, RNA protein and cellulose.

Even when there is no organized shoot tip or meristem or no newly engineered information, the tissue culturist knows that cells may respond metabolically to the external variables of light, temperature and nutrition. Better control over morphogenesis or embryo, shoot and root formation for mass production is of high priority, so that recombinant DNA technologies can be applied to woody species. In woody perennials, more so than in animals or microorganisms, the regulation of morphogenesis is vested in responses to not only growth regulators but to correlations in the body of the tree with nutrition and environmental factors - the length of day, in day and night 
temperature fluctuations, the seasons and water. Therefore, the reductionist approach, which has accumulated much detail about plant cells in test tubes, needs to be balanced by a more integrated, holistic perspective.

- Second, commercial applications of cell and tissue culture and associated technologies remain limited even where plants can be regenerated from cells. For example, in the genetic engineering of plant cells, gene transfer and expression are not yet very efficient and are limited to a few host systems (Fox 1981). The long-term genetic stability of the cloning vehicles themselves is untested. Furthermore, most of the traits we may be interested in involve more than a single gene.

As for protein quality in seeds, plant storage proteins are usually a collection of subunits, each coded by genes that seem to be highly separated from one another and each of which has multiple expressions. Expression of this sytem in the whole tree seems to be more complicated than first suspected.

- Third, where increased productivity is postulated on hybrid cellular associations, the host cell may have to be modified substantially before the productivity can be realized. For example, if leaky mutants of nitrogen-fixing bacteria were to be fixed to the roots of corn, the plant may not be able to support this type of association. The claim is that corn should be bred to produce sufficient photosynthate to meet the demands arising from the nitrogen released by the bacteria (Brill 1981). An increase in current levels of productivity will involve factors of which we may have insufficient knowledge and control. In contrast, at the cellular level, when protoplasts from two different but genetically related plants are fused and where a hybrid plant can be regenerated, the hybrid, such as a potato and tomato, bears fruit that is a blend of characteristics rather than separate entities, such as potatoes in the ground and tomatoes hanging on stems (Melchers 1980). More product specificity and less incompatibility and somaclonal aberration is needed if such technologies are to be applied to woody perennials.

- Fourth, we cannot yet guarantee that the trees propagated through cell and tissue culture will always be uniform or fully responsive to past methods of cultivation (Kester 1976. Durzan 1984b). The excised tissues of the more commercially important, long-lived woody species tend to remember their original position and age in the tree and continue to express this even when separated from the donor (Durzan 1984a). For reasons unknown, genetically identical copies may develop differently, either physiologically or morphologically, and this may add to the overall variability. This somaclonal variation has been touted as being useful. The value of these aberrations remains to be proven (Durzan 1984b). Until cell and tissue culture methods can be applied to older and genetically proven specimens, the utility of this method will remain limited. Recently, progress has been encouraging on this front.

- Fifth, once forest trees can be mass-produced, we are not sure how well the plantlets will transfer from the culture chamber to the field. Where physiological and nutritional preconditioning is required, large-scale transfers to the field may be difficult, especially where the propagules are ejected by frost or heaving soil erosion. Nevertheless, nurseries that can deal with millions of plants at once are available, especially for coniferous species and some horticultural varieties.
- Sixth, can tissue culture produce trees at a reasonable price? For the boreal forest the aim is to produce a softwood propagule at a cost of a few cents. Ornamental and fruit trees can absorb much higher costs. For easy-to-root hardwood species, such as red maple or locust, the production cost per 1000 containerized and improved seedlings would be approximately $\$ 125$ (US) or just over 12 cents each (Brown and Sommer 1982). Although production costs seem acceptable, costs over the entire cycle of cultivation and harvesting remain undetermined.

- Seventh, can agroforestry systems be established through tissue culture to meet human needs? In developing countries, multiple-use agriculture and forestry systems with short rotations are sought for energy and food (PinstrupAndersen 1981, Crosson 1982). With some or most tree species, the hope is that tissue culture will, by capturing genetic gains, help to provide trees that can flourish in the changed environment that results from human intervention.

The impact of biomass energy cropping on poor sites (as with Eucalyptus species) depends on a complex set of factors. These vary from one location to another and include available technologies, climate, growth of demand for food, fibre and energy, per hectare yields, and the amount of land that can be brought into production at acceptable economic and environmental costs. There are no sound, well-established, scientific generalizations for predicting over the long term the best cultural treatment for a new unit or mix of vegetation. We may therefore have to look to the experience of countries with natural forest.

\section{Summary: Concerns and Priorities}

Biotechnology, applied to trees, is a new tool. It has contributed to and been affected by explosive recent developments in science. Biotechnology provides a vehicle for selecting and shaping our genetic resources.

By anticipating production problems, processes and socalled elite trees can be rejected as likely to fail or be modified to improve their chances for success. Therefore, we need examples where biotechnology is a good model for the realworld situation that could benefit from this type of innocation (Evenson et al. 1979).

Biotechnology needs to be trimmed of unimportant details and simplified to make it speedy and inexpensive. It should be able to add high technology to plant genetic resources for multiplier effects in the marketplace (Shapiro 1978ab, Bradbury 1981).

According to Rumburg (1984, see also Daedalis 1980) biotechnologies in agriculture depreciate and become obsolete. They must be repaired, maintained and updated. They do not all depreciate at the same rate; in some cases updating technology may be equivalent to standing still. Furthermore, the time taken by new technologies to come into broad use varies (Davies and Lawrenson 1978).

The application of biotechnology to forestry calls for realism and balance: the overall program should be aimed at the goals of the enterprise and advances scheduled so that important problems will be solved neither too early nor too late to support these goals. Quality results are needed to lower overall costs so that returns on investment support the enterprise 
and provide resources for further research and development (Davies and Lawrenson 1978).

The hope is that costs of producing bulk materials and commodities will be progressively reduced. Older technologies will eventually become outmoded but current agricultural or forestry practices may coexist.

The pattern of progress will be determined, it seems, by the established techniques and learning experiences that are currently leading to increased productivity and cost-savings.

Biotechnology as applied to the domestication of genetic resources is a key ingredient in developing germplasm for energy, food and chemical feedstocks. The adequacy of forest products depends on timely support for this approach to research and development. The prudent course seems to be to support biotechnologies but meanwhile to be sensitive to the longer-term implications of how genetic resources and land are used.

Agriculture is now moving from primitive to more advanced production-use cycles (Dahlsten 1976). This development includes more complex agroforestry systems with shortened rotations. Hence, we must broaden our arsenal of biotechnologies. Science and technology are moving from a base classical physics and chemistry to one more representative of biological systems.

Integration and refinement of production cycles (Fig. 1) is expected to provide high-tech competitive advantages and ease problems in soil-water conservation, plant productivity, human nutrition, commodity delivery and perhaps even animal productivity (as in aquaculture and agroforestry). We must ask how biotechnology can fit into production schemes and how it will enable us to reduce our dependence on nonrenewable resources. Systems and services will have to permit growth of an appropriate infrastructure and development of new markets and alternative use cycles.

\section{References}

Baum, R.M. 1984. Genetic engineering engulfed in new environmental debate. Chem. Eng. News, Aug. 13: 15-22.

Bonga, J.M. and D.J. Durzan, eds. 1982. Tissue Culture in Forestry. Martinus Nijhoff, The Hague, $420 p$

Bradbury, F.R. 1981. Technological economics. Innovation, project management and technology transfer. Sci. Rev. 6: 142-154.

Brill, W.J. 1981. Agricultural microbiology. Sci. Amer. 245(a): 198-215.

Brill, W.J. 1985. Safety concerns and genetic engineering in agriculture. Science 227: 381-384

Brink, R.A. 1962. Phase change in higher plants and somatic heredity. Q. Rev. Biol. 37: 1-22

Brown, C.L. and H.E. Sommer. 1982. Vegetative propagation of dicotyledenous trees. In Tissue Culture in Forestry. J.M. Bonga and D.J. Durzan, eds. Martinus Nijhoff, The Hague, p. 109-149.

Calgene, 1984. Annual Report, Davis, CA

Crosson, P.R., ed. 1982. The Cropland Crisis. John Hopkins Pr., Baltimore.

Daedalis. 1980. Modern technology. In Proc. Amer. Acad. Arts and Sciences, 109: 190

Dahlsten, D. 1976. The third forest. Environment 18: 35-42

Davies, D.S. and I. Lawrenson. 1978. Strategies for technologies with long lead times. In Resources of Organic Matter for the Future. L.E. St. Pierre, ed. Multiscience Pub. Co., Montreal. p. 177-184

Durzan, D.J. 1980. Progress and promise in forest genetics. In Proc 50th Anniversary Conf., Inst. of Paper Chem., Appleton, USA, May 8-10, 1979. p. 31-60.
Durzan, D.J. 1982. Cell and tissue culture in forestry. In Tissue Culture in Forestry. J.M. Bonga and D.J. Durzan, eds. Martinus Nijhoff, The Hague. p. 36-71.

Durzan, D.J. 1984a. Special problems: Adult vs. juvenile explants. In Handbook of Plant Cell Culture, Crop Species. W.R. Sharp et al., eds. MacMillan, New York. 2: 471-503.

Durzan, D.J. 1984b. Potential for genetic manipulation of forest trees: Totipotency, somaclonal aberration, and trueness to type. In Proc. Int. Symp. Recent Advances in Forest Biotechnology, July $10-13,1984$, Michigan Biotechnology Institute, Traverse City. p. 104-125

Durzan, D.J. 1985a. Tissue culture and improvement of woody perennials: An overview. In Plant Tissue Culture: Application to Agriculture and Forestry. Presented at symposium on Plant Cell and Tissue Culture, September 9-14, 1984, Univ. Tennessee, Knoxville. In press.

Durzan, D.J. 1985b. Nitrogenous extractives extracellular to the lignocellulosic cell wall. In Natural Products Extraneous to the Lignocellulosic Cell Wall of Woody Plants. J.W. Rowe, ed. Springer-Verlag, New York. Chap. 4. In press.

Durzan, D.J. 1985c. Micropropagation in industry: Trees, ornamentals. Presented at 36 th Annual Meeting, Tissue Culture Association, June 2-6, New Orleans.

Durzan, D.J. and R.A. Campbell. 1974. Prospects for the mass production of improved stock of forest trees by cell and tissue culture. Can. J. For. Res. 4:151-174

Evenson, R.E., P.E. Waggoner and V.W. Ruttan. 1979. Economic benefits from research: An example from agriculture. Science 205: $1101-1107$

Fox, J.L. 1981. More nutritious corn aim of genetic engineering Chem. Eng. News, Dec. 7. p. 31-34.

Gupta, P.K., U.J. Mehta and A.F. Mascarenhas. 1983. A tissue culture method for rapid clonal propagation of mature trees of Eucalyptus torelliana and Eucalyptus camaldulensis. Plant Cell Reports.

Hanson, D.J. 1984. Government readies rules for biotechnology control. Chem. Eng. News, Aug. 13. p. 34-38.

Kester, D.E. 1976. The relationship of juvenility to plant propagation. In Proc. Int. Plant Propagation Society. 26: 71-84.

KInloch, B.B. Jr., G.K. Parks and C.W. Fowler. 1970. White pine blister rust: Simply inherited resistance in sugar pine. Science 167: 193-195.

Lower, A.R.M. 1938. The North American Assault on the Canadian Forest. Ryerson Pr., Toronto.

Maugh, T.M. 1984. Tracking exposure to toxic substances. Science 226: $1183-1184$

Melchers, G. 1980. The somatic hybrids between tomatoes and potatoes (topatoes and pomatoes). In Plant Cell Culture: Results and Perspectives. F. Sala et al., eds. Elsevier-North Holland. p. 57-58.

O'Sullivan, D.A. 1984. CHEMRAWN conference probes future chemical feedstocks. Chem. Eng. News, Aug. 20. p. 63-67.

Paszkowskl, J., R.D. Shillito, M. Saul, V. Mandak T. Hohn and I. Potrykus. 1984. Direct gene transfer. EMBO J.12:2717-2722.

Pinstrup-Andersen, P. 1981. Energy cropping. Mazingira 5 (1): 60-69.

Rumburg, C.B. 1984. Scientific requirements for maintaining technology and developing human capital. In Reference Document: Needs Assessment for the Food and Agricultural Sciences. Joint Council on Food and Agriculture Sciences, USDA Washington. p. 291-301

Ryder, E.J. 1984. The art and science of plant breeding in the modern world of research management. Hort Science 19: 12-15.

Shapiro, I.S. 1978a. Introductory overview and perspective of the world chemical industry. In Resources of Organic Matter for the Future. L.E. St. Pierre, ed. Multiscience Publishing, Montreal. p. 25-34.

Shapiro, I.S. 1978b. Future sources of organic raw materials. Science 202: 287-289.

Sparrow, A.H., S.S. Schwemmer and P.J. Bottino. 1970. Survival of food crops and livestock in the event of a nuclear war. Symp. Ser. 24 on nuclear war. Atomic Energy Commission, Washington. 
Timmis, R. and G.A. Ritchie. 1984. Progress in Douglas-fir tissue culture. In Proc. Int. Symp. Recent Advances in Forest Biotechnology, June 10-13, 1984. Michigan Biotechnology Institute, Traverse City. p. 37-46.

US Dept. of Agriculture (USDA). 1971. Genetics are sex. Forest Service Pamphlet. USDA Forest Service, Milwaukee.

Vane, J. and P. Cuatrecasas. 1984. Genetic engineering and pharmaceuticals. Nature 312: 303-305.
Varrin, R.D. and D.S. Kukich. 1985. Guidelines for industrysponsored research at universities. Science 227: 385-388.

Venkatasubramanian, K., A. Constantinides and W.R. Vieth eds. 1983. Biochemical engineering III. Ann. N.Y. Acad. Sci., Vol. 431. 